Volume 13

Issue 3 Critical Genocide and Atrocity

Prevention Studies

$12-20-2019$

\title{
Film Review: Radical Evil
}

Raya Morag

Follow this and additional works at: https://digitalcommons.usf.edu/gsp

\section{Recommended Citation}

Morag, Raya (2019) "Film Review: Radical Evil," Genocide Studies and Prevention: An International Journal: Vol. 13: Iss. 3: 176-177.

DOI:

https://doi.org/10.5038/1911-9933.13.3.1722

Available at: https://digitalcommons.usf.edu/gsp/vol13/iss3/18

This Film Review is brought to you for free and open access by the Open Access Journals at Digital Commons @ University of South Florida. It has been accepted for inclusion in Genocide Studies and Prevention: An International Journal by an authorized editor of Digital Commons @ University of South Florida. For more information, please contact digitalcommons@usf.edu. 
Das radikal Böse (Radical Evil)

Director: Stefan Ruzowitzky

Germany/Austria, 2013

Reviewed by Raya Morag

The Hebrew University

Radical Evil, ${ }^{1}$ Stefan Ruzowitzky's documentary film, begins with a motto by Holocaust survivor and author Primo Levi: "Monsters exist, but they are too few in number to be truly dangerous. More dangerous are the common men, the functionaries ready to believe and to act without asking questions." 2 This motto portends the film's unique representation of the major enigma of the twentieth century, that of the ordinary man who becomes a monstrous perpetrator.

Ruzowitzky, the director (and scriptwriter), a member of the third generation (his grandfather was a Nazi), uses three audial sources to reflect on the enigma of the ordinary man, which is the subject of his film: original quotes taken from the diaries and letters of the Nazi death squads, the Einsatzgruppen, who shot some two million Jewish civilians in Eastern Europe during World War II; (excerpts from) Head of the SS Heinrich Himmler's Posen speech from early October 1943, given in Nazi-occupied Poland before officials of the Nazi party; ${ }^{3}$ and interviews with psychiatrists; historians; genocide experts; and ninety-three-year-old Benjamin Ferencz, one of the chief prosecutors at the Nuremberg trials.

The Einsatzgruppen quotes are read by well-known German actors (such as Devid Striesow (The Counterfeiters, and Downfall ${ }^{4}$ ), Alexander Fehling (Inglorious Basterds and Labyrinth of Lies $^{5}$ ), and Volker Bruch (The Baader Meinhof Complex and The Reader $\left.{ }^{6}\right)$ ), whose voices are familiar to German, Austrian, as well as global spectators. In contrast, nonfamiliar actors reenact the death squads' lives and deadly acts: watching Nazi propaganda films, vomiting after the first massacre, shaving before the next day of executions begins, and taking pictures together. Their anonymity, symbolizing the faceless Nazi masses, stands in contrast to the familiar voices of the actors who speak "in their place." I suggest that the perpetrator's voice, attached to and based on the enigma, and in contrast to the victim's, is "replaceable" because it symbolizes the non-integrity of the voice's owner, his denial. Immersed in denial, the perpetrator's disembodied, replaceable voice is not the expression of the speaker's inner essence, a guarantee of the Truth. Thus, it signifies an immanent split between truth and its utterance, the voice being the (failed) mediator. The "exchanged" voice becomes that which radically undermines the possibility of self-expression and self-presence, insofar as it reveals the rupture at the core of the perpetrator' subjectivity. The actors' voices invest the quotes from the diaries and letters with a dramatization that makes them alive but, due to the self-reflexive irony of their immediate identification as cinematic celebs, paradoxically also keep the horror at a distance. Most importantly, I suggest that it is this uncanny combination of the familiar

\footnotetext{
${ }^{1}$ Winner of the Avner Shalev Yad Vashem Chairman's Award at the Jerusalem International Film Festival, 2014.

2 The quote is taken from Primo Levi, Reawakening (New York: Touchstone, 1995), 228.

3 The recordings are the first known documents in which a high-ranking German member of the Nazi government speaks of the ongoing extermination of the Jews in extermination camps. They demonstrate that the German government planned and carried out the Holocaust.

${ }^{4}$ Stephan Ruzowitzky, The Counterfeiters (Die Fälscher), (Austria/Germany: Studio Babelsberg, 2007); Oliver Hirschbiegel, Downfall (Der Untergang), (Germany/Austria/Italy: Constantin Film, 2004).

${ }^{5}$ Quentin Tarantino, Inglorious Basterds (Germany/USA: Universal Pictures, 2009); Giulio Ricciarelli, Labyrinth of Lies (Im Labyrinth des Schweigens), (Germany: Claussen+ Wöbke+Putz Filmproduktion, 2014).

${ }^{6}$ Uli Edel, The Baader Meinhof Complex (Der Baader Meinhof Komplex), (Germany/France/Czech Republic: Constantin Film, 2008); Stephen Daldry, The Reader (USA/Germany: Mirage Enterprises, 2008).
} 
sound with the unfamiliar image, the gap between body and voice, deed and reflection, that calls for the spectators' recognition.

The second audial source, the unmistakable recorded voice of Himmler, is intertwined within the Einsatzgruppen accounts and thus assists in enhancing the sensation of authenticity. The third audial source, interviews with renowned researchers (such as the Harvard psychiatrist Robert J. Lifton, the author Christopher R. Browning, and the priest Patrick Desbois ${ }^{7}$ ) who attest to the major insights achieved in research during the last seventy-three years, have an accumulating effect. Thus, when the film represents the results of prominent psychological experiments (of Solomon Asch, Stanley Milgram, and Philip Zimbardo) directed at the topic, the camera is located above the experiments, which are presented through minimal graphic means. Providing a high angle gaze, the camera once again raises the question of proximity and distance from Evil and from past events. Ruzowitzky uses a split screen such that a line of boots is juxtaposed with a close-up on the face of one of the soldiers, thus raising both Holocaust iconography and reflexively reflecting on it, while calling for the spectators' awareness of the pervasiveness of these images. Benjamin Ferencz closes this complex discussion by emphasizing that out of the 3,000 soldiers of the death squads, only twenty-four were put on trial (due to lack of seats at court). Fourteen of them were sentenced to death, but the verdict was carried out in only four cases. All the others served various periods in prison and were released in 1958. According to Ferencz, the court failed in this mission.

In its unique cinematic language, I suggest, Radical Evil adheres to Dominick LaCapra's suggestion that there is a

tendency to restrict explanations to two broad, binaristically opposed options: (1) the role of industrialized mass murder, bureaucracy, the machinery of destruction, "desk murder," the banality of evil, and the behavior of ordinary men in extraordinary circumstances and (2) the role of perpetrators as anti-Semitic, cruel, sadistic, gleeful monsters. Moreover, the second option may be criticized solely predominantly in terms of the first. ${ }^{8}$

This is done by juxtaposing these options mainly through the various uses of sound. In this, though the film does not include a victim's testimony and thus its presentation of the Holocaust trauma is indirect and non-emotional, its multi-layered presentation of the perpetrator's figure and symbolic and real voice demands the spectators' ethical response to the immanent tensions and paradoxes embodied in this enigma. The overall interpretation that arises from the film's connection between the perpetrators' audial accounts and the outcomes of the experiments marks the major achievement of this film. When members of the third generation in Germany read the accounts of the Einsatzgruppen they undoubtedly position themselves in their place, symbolically embodying their voice. However, Ruzowitzky's cinematic language addresses global spectators as well, constantly reminded them that as the catastrophic events that have taken place during the first two decades of the twenty-first century prove, this irresolvable enigma should still haunt each and every one of us.

Title of the Film: Das radikal Böse (Radical Evil); Director: Stefan Ruzowitzky; Producers: Kurt Otterbacher, Wolfgang Richter; Screenplay: Stefan Ruzowitzky; Cinematography:

7 Desbois founded an organization aimed at locating the sites of mass graves of Jewish victims of the Einsatzgruppen in the former Soviet republics and the Eastern bloc.

${ }^{8}$ Dominick LaCapra, Writing History, Writing Trauma (Baltimore: Johns Hopkins University Press, 2001), 125. 
Benedict Neuenfels; Film Editor: Barbara Gies; Sound Designer: Tatjana Jakob; Cast: Devid Striesow, Alexander Fehling, Volker Bruch; Countries: Germany/Austria; Language: German; Year of Production: 2013; Production Company: W-Film; Duration: 96 minutes. 